\section{Listeria monocytogenes contamination in industrial sausages}

\author{
Contaminação por Listeria monocytogenes em salsichas \\ industriais
}

\section{Carla Susana Rodrigues ${ }^{1,2}$, Claudia Valeria Gonçalves Cordeiro de Sá2 \& Cristiano Barros de Melo}

'Official veterinarian - AFFA, MSc., Graduate student in Animal Sciences. Programa de Pós-graduação em Ciências Animais PPGCA, Universidade de Brasília - UnB, Brasília, DF, Brasil

${ }^{2}$ Official veterinarian - AFFA, Dr. Departamento de Inspeção de Produtos de Origem Animal - DIPOA, Ministério da Agricultura, Pecuária e Abastecimento - MAPA, Brasília, DF, Brasil

${ }^{3}$ Veterinarian, Dr., Professor. Programa de Pós-graduação em Ciências Animais - PPGCA, Universidade de Brasília - UnB, Brasília, DF, Brasil

\begin{abstract}
Listeria monocytogenes is the pathogen responsible for listeriosis foodborne outbreaks, which is a serious disease for animals and humans, mainly elderly, children and pregnant women. Listeriosis can progress to encephalitis, meningitis and septicemia, and cause miscarriage, foetal death or neonatal infection. The aim of the current study was to estimate the occur ence of $L$. monocytogenes in sausages produced by Brazilian companies registered at the Federal Inspection Service (SIF) and discuss issues related to possible contamination. Samples were collected by the official service from companies throughout Brazil. Analyses were performed in official laboratories of the National Agricultural Laboratories Network (LANAGRO), accredited by ISO 17025. During the study period, 98 samples of sausages were analysed and L. monocytogenes was detected in $8.16 \%$ of the samples (8/98). Six sausage companies were found positive for $L$. monocytogenes, where cross-contamination occurred after heat treatment and prior to product packaging, favouring the presence of this pathogen. Given that sausage is a cooked meat product that may or may not be heated prior to consumption, and is appreciated mainly by children, this, therefore, poses a risk to consumers. This result highlights that it is essential to intensify compliance with good manufacturing practices and to adopt risk mitigation measures to avoid this pathogen.
\end{abstract}

Keywords: foodborne disease, food safety, listeriosis, sausage.

\section{Resumo}

Listeriose é uma séria doença de animais e humanos, geralmente transmitida por alimentos contaminados por Listeria monocytogenes, como por exemplo, as salsichas. Diante disso, o objetivo do presente estudo foi estimar a ocorrência de L. monocytogenes em salsichas industriais produzidas em estabelecimentos registrados no Serviço de Inspeção Federal (SIF) no Brasil e discutir questões relacionadas a contaminação. Assim, 98 amostras de salsichas foram coletadas oficialmente em indústrias no país e as análises foram realizadas nos laboratórios da Rede de Laboratórios Nacionais Agropecuários (LANAGRO), acreditados na NBR ISO 17025. A presença de L. monocytogenes foi detectada em 8,16\% (8/98). Também, foi demonstrado que em seis (6) indústrias onde houve detecção de L. monocytogenes e a contaminação ocorreu após o tratamento térmico e antes da embalagem das salsichas. Considerando que salsicha é um alimento pronto e que pode ou não ser aquecida antes do consumo, além de ser apreciada por crianças, a contaminação aqui demonstrada pode representar um risco à saúde do consumidor. Esse resultado demonstra que é essencial intensificar o monitoramento e a implementação das boas práticas de produção, com foco em mitigar o risco para esse patógeno.

Palavras-chave: doença transmitida por alimento, embutido, listeriose, segurança alimentar. \section{B] M Brazilian Journal of Veterinary Medicine \\ p-ISSN 0100-2430 e-ISSN 2527-2179

How to cite: Rodrigues, C. S., Sá, C. V. G. C \& Melo, C. B (2018). Listeria monocytogenes contamination in industrial sausages. Brazilian Journal of Veterinary Medicine, 40, ELOCATION. e009118. http://dx.doi.org/10.29374/2527-2179. bjvm009118

Financial support: This project was partially funded by CAPES. The author C.B de Melo is CNPq's productivity scholarship holder (PQ).

Conflict of interests: No conflict of interests declared concerning the publication.

Received: September 06, 2017.

Accepted: October 03, 2018.

The study was carried out at Programa de Pós-graduação em Ciências Animais PPGCA, Universidade de Brasília - UnB and at Departamento de Inspeção de Produtos de Origem Animal - DIPOA, Ministério da Agricultura, Pecuária e Abastecimento - MAPA Brasília, DF, Brasil.

\section{*Correspondence}

Cristiano Barros de Melo

Programa de Pós-graduação em Ciências

Animais - PPGCA, Universidade de Brasília

- UnB

Campus Darcy Ribeiro, Asa Norte

CEP 70910-000 - Brasília (DF), Brasil

E-mail: cristianomelo@unb.br 


\section{Introduction}

Listeriosis is caused by Listeria monocytogenes, which is considered a severe disease for children, people over 65 years old and those with compromised immune systems. This pathogen can cause encephalitis, meningitis and septicemia, whereas in pregnant women it may result in miscarriage, foetal death, premature birth and neonatal infection, which might evolve to meningitis, septicemia and death of the newborn. Despite its low incidence, especially compared to other foodborne diseases, listeriosis causes a severe clinical condition and a high mortality rate, ranging between 15\% and 30\% of all affected individuals (Todd \& Notermans, 2011; Cartwright et al., 2013).

Although $L$. monocytogenes is found in a variety of foods, most outbreaks and sporadic cases in humans are associated with ready-to-eat meat, dairy and fish products that can be eaten without any heat to eliminate or reduce the number of bacterial cells to acceptable levels (Cartwright et al., 2013; European Food Safety Authority, 2015).

As has occurred in other countries, listeriosis may become an important foodborne disease in Brazil. This is expected due to changes in eating habits in recent decades, which has resulted in an increased consumption of industrialised and minimally processed foods by vulnerable populations. In Brazil, between 2000 and 2015 (data until May/15), 10,666 outbreaks of foodborne diseases were officially reported, with 209,240 patients and 154 deaths. Approximately $20.2 \%$ of these outbreaks were associated with eggs, products containing eggs, milk and dairy products, beef, pork, poultry, fish, seafood and fishery products. In only $41.9 \%$ of these outbreaks, the etiologic agent was identified and none of these agents were related to L. monocytogenes in Brazil (Brasil, 2015).

L. monocytogenes is frequently detected in different foods marketed in Brazil, as well as from hospitalised patients (Reis et al., 2011), but without an association with the consumption of a particular food; thus, it can be inferred that there is a high possibility of under reporting of listeriosis in Brazil. Lack of hygiene during slaughter leads to the faecal contamination of the meat and the industrial facility. In addition, failures to comply with good manufacturing and hygiene practices allow the bacterium to be carried into the company, where it can survive for long periods due to its ability to form biofilms and resist bacterial agents that cause microbial stresses (Mendonça et al., 2012; Cartwright et al., 2013; Brasil, 2015).

Sausage is a cooked meat product with intrinsic and extrinsic characteristics favourable for the development of $L$. monocytogenes during its shelf life. In Brazil, it is an accessible food, enjoyed by children, adults and seniors, and it may or may not be heated prior to consumption (Cesar et al., 2011; Mendonça et al., 2012). In 2013, there were 95 sausage-producing companies under the Federal Inspection Service(SIF) in Brazil, producing more than 1 billion tons of sausages. The aim of the current study was to estimate the occurrence of $L$. monocytogenes in sausages produced by Brazilian companies registered at the Federal Inspection Service (SIF) and to discuss issues related to possible contamination.

\section{Material and methods}

To identify L. monocytogenes contamination in sausages manufactured by companies under SIF, at least 97 samples were required. Sample size calculations were performed according to Thrusfield (2004), with an expected contamination of 10\% (Lambertz et al., 2012; Kramarenko et al., 2013), confidence level of $90 \%$ and a desired absolute precision (absolute error) of 5\%. Thus, from August 2013 to December 2014, we analysed 98 samples of sausage collected by the Official Service in 61 companies located in 12 federative units (UF) of Brazil. Hot dog, frankfurter, Viennese and poultry sausage samples were analysed.

Official procedures were adopted for sampling, packaging and sending these samples to the laboratory; namely collection was performed by the SIF, a civil servant of the Ministry of Agriculture, Livestock and Food Supply (MAPA), sample identification and an official request for analysis was completed. Samples were packaged in a numbered plastic bag or in a plastic bag with numbered seals affixed in such a way so as to ensure the inviolability of the sample, transported in isothermal boxes and received by the laboratory after verification of the identification data and their conservation status. 
Samples were received in the laboratories of the National Agricultural Laboratories Network (LANAGRO) by trained employees and in accordance with official procedures, taking into account good laboratory practices for receiving samples for analysis. During the receiving process, the integrity of the samples was checked, as well as its documentary traceability and reliability (without readable information), its original packaging (in the same presentation as the that intended for the consumer, to avoid the collection of samples sent specifically to the laboratory) and the quality of the packages. Samples were accepted in clean, undamaged packages, without perforations or cracks, preferably in their original packaging, and when this was not possible, in suitable containers, with no signs of tampering, sealed in an inviolable manner and without signs of leakage or rupture. All samples were given univocal identification at the time of their arrival to the laboratory; such identification was recorded in a specific form or in the appropriate computerised system with date and time of receipt. A copy of the official request was filed in an organised and traceable form, including in a digital form (Brasil, 2017).

Analyses were conducted in LANAGRO laboratories, accredited in ISO 17O25, located in Porto Alegre, RS, Campinas, SP, Pedro Leopoldo, MG, Goiânia, GO and Recife, PE. The microbiological analysis was performed according to VIDAS Listeria monocytogenes II (VIDAS LMO2), which is an internationally recognised methodology and is recommended by the Ministry of Agriculture, Livestock and Food Supply; results were confirmed by the reference method ISO 11290-1:1996 / ISO 11290-1:1996 Amd. 1:2004.

VIDAS LMO2 is an alternative method that has been validated for the detection of Listeria monocytogenes; this is in comparison to the reference method ISO 11290-1, evaluated by AOAC as an official method (2004.02). This test is an automated enzyme-linked fluorescent immunoassay for the detection of L. monocytogenes in food. The LMO2 test, following the enrichment procedure from the MFLP-33 method, also included use of the chromogenic media, chromID Ottaviani Agosti Agar (OAA) and chromID Lmono for confirmation of LMO2 presumptive results (Johnson \& Mills, 2013). Johnson \& Mills (2013) demonstrated that the VIDAS LMO2 method is an acceptable alternative method to the MFHPB-30 standard culture method for the detection of L. monocytogenes in ready-to-eat (RTE) meats, including liver paté, hot dogs, raw fermented sausage, sliced deli turkey and sliced deli ham.

VIDAS Listeria monocytogenes II was also validated for the detection of Listeria monocytogenes by AFNOR Certification following the validation protocol ISO 16140-2. This decision attests that the alternative analysis method has been assessed by AFNOR Certification and found to conform to the standards and complementary requirements, as specified in the certification reference document. The principal certified characteristics are the "analytical performances", as defined in the associated validation study report (sensitivity, relative detection level) available for this certification (AFNOR Certification, 2016).

To determine the sodium chloride content, we used the method described by Brasil (1999). Thus, the determination of sodium chloride content was performed by Method B: Argentometric (Möhr), in which the chlorides are precipitated in the form of silver chloride, in slightly alkaline $\mathrm{pH}$, with the presence of potassium chromate as an indicator. The titration end is visualised by the formation of brick red precipitates of silver chromate.

In Brazil, factories registered with the Federal Inspection Service are monitored by veterinarians and by laboratory tests to verify the conformity of controls carried out by the company to ensure the quality and food safety of the animal-origin products being manufactured. Control of $L$. monocytogenes in ready-to-eat animal products includes products with a $\mathrm{pH}$ greater than 4.4, water activity greater than 0.92 and sodium chloride concentration less than $10 \%$. The $\mathrm{pH}$ value was obtained by measuring the concentration of hydrogen ions in the sample using potentiometry. Activity water was determined according to Brasil (2009).

For more information about the composition and manufacturing process, we requested that a Microsoft Office Excel ${ }^{\circledR}$ spreadsheet be simultaneously filled out during data collection. In addition, the documents presented by the manufacturers to obtain the approval of these products in the SIF were consulted to obtain complementary information about the formulation and manufacturing process. Information about the monthly production of sausages from each company was obtained from the database of the Management Information System of the SIF. 
The present study was officially authorised by the Department of Inspection of Products of Animal Origin - DIPOA of the Secretariat of Agricultural and Livestock Defense of the Ministry of Agricultural, Livestock and Supply (DIPOA/SDA/MAPA) under the process n² 21000.001027/2014-01. For ethical reasons, the identification of companies and the information about their respective production processes were preserved.

\section{Results and discussion}

Despite industry efforts to improve system quality and produce safe food, this study observed a $L$. monocytogenes ooccurrence of $8.16 \%$ (8/98 - confidence interval (CI) $=3.16 \%$ to 13.16\%) in industrial sausage samples produced under the Federal Inspection Service (Table 1). This occurrence is considered high because samples were collected at the manufacturer and analysed at the beginning of their shelf life; this demonstrated that sausage presents favourable conditions for the development of $L$. monocytogenes, therefore, posing a risk to consumers if not heated prior to consumption. Thus, to achieve an adequate level of protection for the consumer, it is essential to intensify compliance with good manufacturing practices and adopt risk mitigation measures to prevent contamination with this pathogen. Approximately 86\% (82/95) of all the sausage producing companies in Brazil were located in the south and southeast, altogether being responsible for about $70 \%$ of the national sausage production (Table 1).

The average shelf life of the sampled sausages was 83 days (standard deviation: 82; shortest shelf life: 29 days; longest shelf life: 365 days [for a frozen sausage]). Most samples (96.43\%) were analysed during the first third of the product's shelf life. The mean observed values for $\mathrm{pH}$, Aw and sodium chloride content were $6.22,0.97$ and $1.62 \%$, respectively, demonstrating that sausages had favourable conditions for $L$. monocytogenes growth during their shelf life (Baka et al., 2015).

Our results are different than those reported in other countries. In Sweden, in 2010, 35 sausage samples collected at retail locations were analysed, with no detection of $L$. monocytogenes (Lambertz et al., 2012). In Australia, the reported prevalence was 2.77\% between 1997 and 2003 (Ross et al., 2009). In Chile, L. monocytogenes were isolated in 5\% of the sausages sampled from 2008 to 2012 (Saludes et al., 2015).

This study also detected six sausage companies positive for $L$. monocytogenes, and observed that cross-contamination occurred after heat treatment and prior to product packaging, favouring the presence of this pathogen. The corrective measures adopted by these industries were related to equipment maintenance, improvement of cleaning procedures, including intensification of environment and equipment sanitisation, and Listeria spp. monitoring on surfaces.

In Brazil, the manufacture of sausages follows the Identity and quality standard set in a technical regulation established by MAPA (Brasil, 2000). Among the 61 companies where samples were collected, in 56 of these companies, it was possible to associate the composition of the product with the collected sample. In 53 companies, it was possible to associate the manufacturing process with the collected sample. Many industrial establishments have more than one approved sausage registration, using different formulations and manufacturing processes. Therefore, when data on composition and manufacturing process were not provided at the time of sample collection, it was not possible to associate this data with the analysed sample.

Table 1. Distribution of samples and results for L. monocytogenes in sausage samples according to geographic region in Brazil.

\begin{tabular}{ccc}
\hline Region of Brazil & Number of analysed samples & $\begin{array}{c}\text { Number of samples with } \\
\text { L. monocytogenes present }\end{array}$ \\
\hline Midwest & 13 & 4 \\
Northeast & 4 & 0 \\
North & 0 & 0 \\
Southeast & 48 & 2 \\
South & 33 & 2 \\
Total & $\mathbf{9 8}$ & $\mathbf{8}$ \\
\hline
\end{tabular}


With regards to the formulation of sausages, the most commonly used ingredients were bovine, porcine and poultry meat, mechanically separated meat obtained from poultry and pork meat, poultry, porcine and bovine fat, porcine masks and skin, pork and poultry skin and liver, heart and kidneys. Among the food additives, the most frequently used stabilizers were sodium pyrophosphate (INS 450i), sodium tripolyphosphate (451i) and sodium polyphosphate (INS 452i). The most frequently used preservatives were sodium nitrate (INS 250) and sodium nitrite (INS 251). The antioxidants were sodium erythorbate (INS 316), carrageenan (INS 407) and acidulant citric acid (INS 330). The acid regulator was sodium lactate(INS 325) and colourings were cochineal carmine and urucum. These were all provided under national legislation (Brasil, 2006).

The sausage manufacturing process has critical points for the microbiological safety of the product with respect to $L$. monocytogenes. In general, the manufacturing process included the comminution of meat and blending with other ingredients and food additives, emulsification, artificial or natural wrap-in, cooking, cooling, unwrapping and packaging (Pardi et al., 2007).

There were 53 evaluated manufacturing processes described by the manufacturers to obtain the registration of the product in the SIF. After cooking, we observed variation in the order of the steps of the manufacturing process. The most frequent order was the cooling of the sausage, unwrapping (when using artificial wrapping), immersion in a colouring tank followed by a colouring fixing tank and packaging. For sausages that do not use colouring, the product was packed soon after unwrapping. Sausages stuffed in natural wrapping and without colouring were cooled and then packaged. Another observed order was, after cooking, the immersion of the sausages in the colouring tank followed by the colouring fixing, cooling, unwrapping and packaging tank.

In the manufacturing process, cooking is considered a listericidal heat treatment because it eliminates or reduces $L$. monocytogenes to acceptable levels. The mean temperature and time reported in the studied manufacturing processes was $72.8^{\circ} \mathrm{C}$ ( (tandard deviation $=1.94^{\circ} \mathrm{C}$ ) for 86 minutes (standard deviation $=56$ minutes) of the cooking process; these are both higher than the minimum required for the reduction of $6 \log$ of $L$. monocytogenes according to thermal resistance data published by International Commission on Microbiological Specifications for Foods (1996), Van Asselt \& Zwietering (2006) and Aryani et al. (2015).

The subsequent steps of the manufacturing process require special attention with respect to the possibility of cross-contamination of the product that has already been submitted to the listericide thermal treatment. Among these steps, the removal of the wrap used to stuff the sausage is considered critical because it exposes the already cooked product, increasing the risk of cross-contamination by L. monocytogenes present in industrial facilities. Among the different industrial establishments studied, 79.24\% declared that they remove the artificial wrap before packaging. For processes in which unwrapping occurs, risk can be mitigated by heat treatment of the sausages after packaging. From the evaluated data, this procedure is still under-utilized, and when it is used, it is done by immersing the packets in hot water until the product reaches $72^{\circ} \mathrm{C}$. However, this procedure is limited by the size of the package, being applied only to smaller packages containing 6 to 12 sausages.

For the eight samples in which L. monocytogenes was detected, it was not possible, in this study, to identify characteristics of the sausage composition or of the manufacturing process that could favour the presence and development of this pathogen. Despite industry efforts to improve their quality systems and produce safe foods, the potential for contamination of sausages by L. monocytogenes is high, considering that the samples were collected in the manufacturing facilities and analysed at the beginning of the shelf life, and that sausage is a product that presents favourable conditions for the development of this pathogen. Thus, in order to achieve an adequate degree of consumer protection, it is essential to intensify compliance with good manufacturing practices and adopt risk mitigation measures to avoid L. monocytogenes.

From the obtained data, it is possible to develop targets for the reduction of contamination by L. monocytogenes in sausages and, thus, to reach an adequate degree of protection for the consumer. In order to achieve this goal, sausage formulation should be revised to increase the use of barriers to the development of L. monocytogenes, using technological processes capable of reducing the number of viable cells due to possible cross-contamination after heat treatment, intensifying L. monocytogenes monitoring on surfaces that come into direct contact with the food and the environment where the product is handled, in addition to intensifying good manufacturing practices to avoid the presence of the pathogen in industrial facilities. 
Educational measures, as part of a risk communication strategy, targeting individuals at the highest risk for listeriosis and aiming to provide advice on safe ways to consume sausage can also minimise the occurrence of listeriosis. However, the impact of all these efforts needs to be measured by the incidence of listeriosis in the Brazilian population. For this, it is important that this disease is diagnosed and compulsorily notified to the public health agency.

\section{Acknowledgements}

We are grateful to CAPES, to Department of Inspection of Products of Animal Origin-DIPOA - of the Secretariat of Agriculture and Livestock Defense of the Ministry of Agriculture, Livestock and Supply (DIPOA/SDA/MAPA), to General Coordination of Laboratorial Support (CGAL/SDA/MAPA), to National Agricultural Laboratories Network (LANAGRO/CGAL/SDA/MAPA) and to Graduate Program in Animal Sciences of University of Brasilia (PPGCA/UnB).

\section{References}

AFNOR Certification. (2016). Validation of alternative analysis methods. NF 102 - Application to the food industry. VIDAS Listeria monocytogenes II (LMO2). Valid for the detection of Listeria monocytogenes. Certificate n. BIO 12/11-03/04. Saint-Denis: AFNOR

Aryani, D. C., Den Besten, H. M. W., Hazeleger, W. C., \& Zwietering, M. H. (2015). Quantifying variability on termal resistance of Listeria monocytogenes. International Journal of Food Microbiology, 193, 130-138. http://dx.doi. org/10.1016/j.ijfoodmicro.2014.10.021. PMid:25462932.

Baka, M., Noriega, E., Tsakali, E., \& Van Impe, J. F. M. (2015). Influence of composition and processing of Frankfurter sausages on the growth dynamics of Listeria monocytogenes under vacuum. Food Research International, 70, 94-100. http://dx.doi.org/10.1016/j.foodres.2014.12.047.

Brasil, Ministério da Agricultura, Pecuária e Abastecimento. (1999, 21 de julho). Oficializa os Métodos Analíticos Físico-Químicos, para Controle de Produtos Cárneos e seus Ingredientes - Sal e Salmoura, em conformidade ao ANEXO desta Instrução Normativa, determinando que sejam utilizados no Sistema de Laboratório Animal do Departamento de Defesa Animal. (Instrução Normativa no 20, de 21 de julho de 1999). Diário Oficial da República Federativa do Brasil. Retrieved in 2018, September 8, from http://www.consultaesic.cgu.gov.br/ busca/dados/Lists/Pedido/Attachments/470907/RESPOSTA_PEDIDO_Instrucao\%2ONormativa\%2OSDAMAPA\%2020\%20de\%2021.7.1999.pdf

Brasil, Ministério da Agricultura, Pecuária e Abastecimento. (2000, 31 de março). Aprova o regulamento técnico de identidade e qualidade de salsicha (Instrução Normativa no 4, de 31 de março de 2000). Diário Oficial da República Federativa do Brasil. Retrieved in 2017, June 18, from https://www.defesa.agricultura.sp.gov.br/ legislacoes/instrucao-normativa-sda-4-de-31-03-2000,662.html.

Brasil, Ministério da Agricultura, Pecuária e Abastecimento. (2006, 29 de dezembro). Adota o regulamento técnico de atribuição de aditivos alimentares e seus limites das seguintes categorias de alimentos: Categoria 8: Carnes e produtos cárneos (Instrução Normativa n0 51, de 29 de dezembro de 2006). Diário Oficial da República Federativa do Brasil, Retrieved in 2017, June 18, from http://extranet.agricultura.gov.br/sislegis-consulta/ consultarLegislacao.do?operacao=visualizar\&id=8932

Brasil. Ministério da Agricultura, Pecuária e Abastecimento. (2009, 08 de abril). Institui os procedimentos de controle da Listeria monocytogenes em produtos de origem animal (Instrução Normativa n. 9, de 8 de abril de 2009). Diário Oficial da República Federativa do Brasil.

Brasil, Ministério da Saúde. (2015). Doenças Transmitidas por Alimentos. Retrieved in 2017, June 18, from http:// portalsaude.saude.gov.br/index.php/o-ministerio/principal/leia-mais-o-ministerio/653-secretaria-svs/ vigilancia-de-a-a-z/doencas-transmitidas-por-alimentos-dta/11220-situacao-epidemiologica-dados

Brasil. Ministério da Agricultura, Pecuária e Abastecimento, Coordenação Geral de Laboratórios Agropecuários. (2017). Manual de Procedimentos para Laboratórios. Área de microbiologia e físico-química de produtos de origem animal. Brasília: MAPA.

Cartwright, E. J., Jackson, K. A., Johnson, S. D., Graves, L. M., Silk, B. J., \& Mahon, B. E. (2013). Listeriosis outbreaks and associated food vehicles, United States, 1998 - 2008. Emerging Infectious Diseases, 19(1), 1-9, quiz 184 http://dx.doi.org/10.3201/eid1901.120393. PMid:23260661.

Cesar, A. P. R., Mesquita, A. J., Prado, C. S., Nunes, I. A., \& Almeida Filho, E. S. (2011). Listeria spp. e Listeria monocytogenes na produção de salsichas tipo hot dog. Ciência Animal Brasileira, 12(2), 339-352. http://dx.doi. org/10.5216/cab.v12i2.7452.

European Food Safety Authority - EFSA. (2015). Scientific Report of EFSA. The European Union summary report on trends and sources of zoonoses, zoonotic agents and food-borne outbreaks in 2013. EFSA Journal, 11(4), 162.

International Commission on Microbiological Specifications for Foods. (1996). Microbiological specifications of food pathogens (1st ed. 513 p.). London; Melbourne: Blackie Academic.

Johnson, R., \& Mills, J. (2013). VIDAS Listeria monocytogenes II (LMO2). Journal of AOAC International, 96(2), 246-250. http://dx.doi.org/10.5740/jaoacint.GovVal05. PMid:23767346. 
Kramarenko, T., Roasto, M., Meremae, K., Kuningas, M., Põltsama, P., \& Elias, T. (2013). Listeria monocytogenes prevalence and serotype in various foods. Food Control,30(1), 24-29. http://dx.doi.org/10.1016/j.foodcont.2012.06.047.

Lambertz, S. T., Nilsson, C., Brådenmark, A., Sylvén, S., Johansson, A., Jansson, L. M., \& Lindblad, M. (2012). Prevalence and level of Listeria monocytogenes in ready-to-eat foods in Sweden 2010. International Journal of Food Microbiology, 160(1), 24-31. http://dx.doi.org/10.1016/j.ijfoodmicro.2012.09.010. PMid:23141642.

Mendonça, K. S., Michael, G. B., Von Laer, A. E., Menezes, D. B., Cardoso, M. R. I., \& Silva, W. P. (2012). Genetic relatedness among Listeria monocytogenes isolated in foods and food production chain in southern Rio Grande do Sul, Brazil. Food Control, 28(1), 171-177. http://dx.doi.org/10.1016/j.foodcont.2012.04.014.

Pardi, M. C., Santos, I. F., Souza, E. R., \& Pardi, H. S. (2007). Ciência, higiene etecnologia da carne. Ed. UFG: Goiânia, p.855-863.

Reis, C. M. F., Barbosa, A. V., Rusak, L. A., Vallim, D. C., \& Hofer, E. (2011). Antimicrobial susceptibilities of Listeria monocytogenes human strains isolated from 1970 to 2008 in Brazil. Revista da Sociedade Brasileira de Medicina Tropical, 44(2), 173-176. http://dx.doi.org/10.1590/S0037-86822011005000019. PMid:21503548.

Ross, T., Rasmussen, S., Fazil, A., Paoli, G., \& Sumner, J. (2009). Quantitative risk assessment of Listeria monocytogenes in ready-to-eat meats in Australia. International Journal of Food Microbiology, 131(2-3), 128-137. http://dx.doi. org/10.1016/j.ijfoodmicro.2009.02.007. PMid:19327859.

Saludes, M., Troncoso, M., \& Figueroa, G. (2015). Presence of Listeria monocytogenes in Chilean food matrices. Food Control, 50, 331-335. http://dx.doi.org/10.1016/j.foodcont.2014.08.008.

Thrusfield, M. (2004). Inquéritos. In M. Thrusfield (Ed.). Epidemiologia Veterinária. São Paulo: Roca Press, 283p.

Todd, E. C. E., \& Notermans, S. (2011). Surveillance of listeriosis and its causative pathogen, Listeria monocytogenes. Food Control, 22(9), 1484-1490. http://dx.doi.org/10.1016/j.foodcont.2010.07.021.

Van Asselt, E. D., \& Zwietering, M. H. (2006). A systematic approach to determine global termal inactivation parameters for various food pathogens. International Journal of Food Microbiology, 107(1), 73-82. http://dx.doi. org/10.1016/j.ijfoodmicro.2005.08.014. PMid:16274824. 